\title{
PHYSIOGRAPHIC SUBDIVISIONS OF THE CHIRIKOV BASIN, NORTHERN BERING SEA
}





\section{Physiographic subdivisions of the Chirikov Basin, northern Bering Sea}

By D. M. HOPKINS, C. H. NELSON, R. B. PERRY, and TAU RHO ALPHA

STUDiES ON THE MARINE GEOLOGY OF THE BERING SEA GE OLOGICA L S UR VEY PROFES I ONAL PA P E R 759-B

Prepared in cooperation with National Ocean Survey,

National Oceanographic and Atmospheric Administration

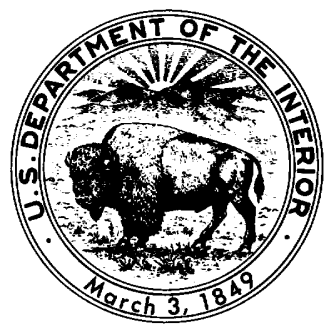




\title{
UNITED STATES DEPARTMENT OF THE INTERIOR
}

THOMAS S. KLEPPE, Secretary

\section{GEOLOGICAL SURVEY}

\author{
V. E. McKelvey, Director
}

Library of Congress Cataloging in Publication Data

Hopkins, David Moody, 1921-

Phy siographic subdivisions of the Chirikov Basin, northern Bering Sea. (Studies on the Marine geology of the Bering Sea)

(Geological Survey Professional Paper 759-B)

Bibliography: $p$.

1. Submarine topography-Chirikof Basin. 2. Chirikof Basin. I. Hopkins, David Moody, 1921-

III. Series. IV. Series: United States Geological Survey Professional Paper 759-B. GC85.2.B47P48 $551.4^{\prime} 65^{\prime} 51$

II. National Ocean Survey. $76-29239$

For sale by the Superintendent of Documents, U.S. Government Printing Office Washington, D.C. 20402

Stock Number 024-001-02917-1 


\section{CONTENTS}

\begin{tabular}{|c|c|c|c|}
\hline & Page & & Page \\
\hline - - - - - - - - - - - & B1 & Physiography-Continued & \\
\hline Introduction & 1 & Offshore physiographic units-Continued & \\
\hline Acknowledgments_........... & 2 & Point Spencer Shoal area-Continued & \\
\hline hysiography & 2 & Tin City Shoal & B4 \\
\hline Nearshore hardrock areas _......... & 2 & Ukivok Shoal _... & 4 \\
\hline shore prograded areas & 2 & King Island Shoal & 4 \\
\hline Offshore physiographic units_. & 3 & Wales Hills & 4 \\
\hline Norton Plain _... & 3 & Clarence Valley & 5 \\
\hline Chirikov Ramp & 3 & Belmezok Area & 5 \\
\hline King Island Valley and Kookoolik Valley & 3 & Prince of Wales Shoal & 5 \\
\hline Chukotka Trough & 3 & Booshu Spur and Sevuokuk Spur & 5 \\
\hline Bering Strait and Chaplino Valleys & 3 & Gambell Shoal & 5 \\
\hline Cape Rodney Parallel Valley Area & 4 & Iga Depression & \\
\hline Point Spencer Shoal Area & 4 & Northeast Cape Shoal and St. Lawrence Trough & \\
\hline er Shoal & 4 & Discussion & \\
\hline York Shoal & 4 & References cited & \\
\hline
\end{tabular}

\section{ILLUSTRATIONS}

Plate 1. Topographic and bathymetric map of the northern Bering Sea region In pocket

2. Orthographic drawing of the northern Bering Sea region

3. Physiographic subdivisions of the Chirikov Basin In pocket

FIgURE 1. Index map showing locations of the Chirikov Basin and bathymetric maps of the northern Bering Sea 


\title{
PHYSIOGRAPHIC SUBDIVISIONS OF THE GHIRIKOV BASIN, NORTHERN BERING SEA
}

\author{
By D. M. Hopkins, C. H. Nelson, R. B. Perry, ${ }^{1}$ and Tau Rho Alpha
}

\begin{abstract}
The Chirikov Basin, a segment of the continental shelf of the Bering Sea that lies north of St. Lawrence Island and south of Bering Strait, is an area of diverse topography and complex relief. The southeastern part is a shallow plain, the northwestern region is undulating and hummocky, and the nearshore zone is more complex. Many relief features of the present-day sea bottom were formed by glacial, fluvial, and littoral erosional and depositional processes during Pleistocene low-sea-level episodes, but they have been modified by submarine erosion and deposition of the past few thousand years.

This paper names and describes the following physiographic units for use in future discussion of the Quaternary tectonic, erosional, and depositional history of northern Bering Sea:
\end{abstract}

Offshore physiographic units

Norton Plain

Chirikov Ramp

Chukotka Trough

Cape Rodney Parallel

Valley Area

Wales Hills

Belmezok Area

Savoonga Depression

St. Lawrence Trough

King Island Valley

Kookoolik Valley

Bering Strait Valley

Port Clarence Valley

Chaplino Valley

\section{INTRODUCTION}

Until recently, the Bering Sea was so poorly known that Dietz and his coworkers could say in 1964 that "the most notable feature of the Bering Sea shelf is its extreme and monotonous flatness." Since 1964, however, detailed surveys have shown the Chirikov Basin ${ }^{2}$ segment of the northern Bering Sea (fig. 1), at least, to be an area of topographic diversity and complex, though hardly rugged, relief (pls. 1 and 2). The topographic complexities, seen against the perspective of

\footnotetext{
'National Ocean Survey, Rockville, MD 20852.

2The Chirikov Basin is one of the "morphological zones" or physiographic provinces in Bering Sea defined by Udintsev, Boichenko, and Kanaev (1959, fig. 6).
}

the extensive sedimentological and geophysical studies of the past few years, provide critical insights into the Cenozoic history of this continental shelf region.

The resource potential of northern Bering Sea ensures that it will be the scene of further scientific study and increasing technological development during the coming decade. Future work there will be facilitated by a better understanding of the geography and topography of the submerged area.

This report is the fruit of cooperative studies of the Chirikov Basin and Norton Sound areas of the northern Bering Sea by the United States Geological Survey and the National Oceanic and Atmospheric Administration. It is based upon recently published bathymetric maps of the northern Bering Sea of scale 1:250,000 (National Ocean Survey Map 1215N-10, 1971, Map $1714 \mathrm{~N}-11$, 1973, Map $1714 \mathrm{~N}-12$, 1973, and Map $1814 \mathrm{~N}-10,1973$ ) (fig. 1) prepared in connection with a search for detrital concentrations of valuable minerals and deposits of hydrocarbons beneath the Bering Sea floor. It names and describes a series of physiographic units for the Chirikov Basin for use in future discus-

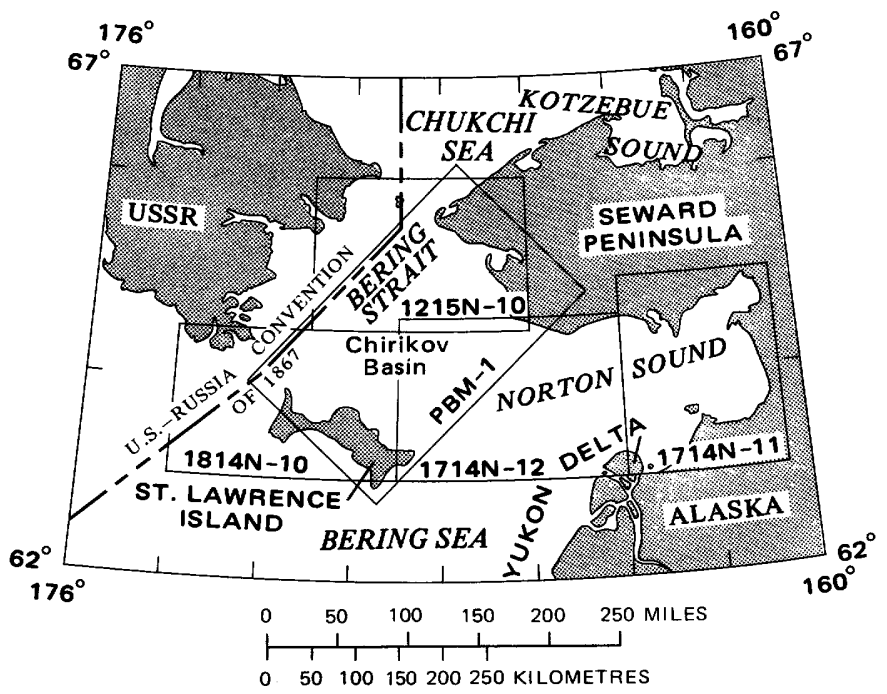

Figure 1.-Locations of the Chirikov Basin and bathymetric maps of the northern Bering Sea. 
sions of the Quaternary tectonic, erosional, and depositional history of northern Bering Sea. Some of the names have already been used in an account of the influence of the Yukon River upon the distribution of bottom sediments in the northern Bering Sea (McManus and others, 1974).

Prior to 1967, little was known of the Bering shelf beyond the reconnaissance studies of Bezrukov and others (1959), Dietz, Carsola, Buffington, and Shipek (1964), Moore (1964), Lisitsyn (1966), Creager and McManus (1967), and Gershanovich (1967). Resourceoriented studies in the northern Bering Sea undertaken during the years $1966-70$ by the U.S. Geological Survey, the U.S. Coast and Geodetic Survey (now the National Ocean Survey of the National Oceanic and Atmospheric Administration), the Marine Minerals Technology Center (then a part of the U.S. Bureau of Mines and later a part of NOAA), and the University of Washington have led to a series of reports and maps that make northern Bering Sea one of the better known continental shelf regions of the world (McManus and others, 1969; Scholl and Hopkins, 1969; Silberman, 1969; Walton and others, 1969; Grim and McManus, 1970; McManus and Smyth, 1970; Moll, 1970; Nelson, 1971; Sheth, 1971; Venkatarathnam, 1971; Hopkins, 1972; Nelson and Hopkins, 1972; Tagg and Greene, 1973; Hopkins and others, 1973; Hood and Kelley, 1974; McManus and others, 1974, 1976; and Nelson and others, 1974, 1975).

\section{ACKNOWLEDGMENTS}

We appreciate the perceptive work of John McAlinden and Carl Fefe and their fellow cartographers of the NOAA Oceanographic Mapping Group in compiling and producing the bathymetric charts upon which this study was dependent. The original hydrographic data were gathered by the National Ocean Survey vessels, Oceanographer, Surveyor, and Rainier. Chindi Hopkins and Robert E. Nelson assisted us with the compilation of the topographic and bathymetric map of the northern Bering Sea region (pl. 1).

\section{PHYSIOGRAPHY}

The Chirikov Basin and Norton Sound are regions of subdued but diversified bottom relief (pls. 1 and 2). The sea is shallow, no part being deeper than $60 \mathrm{~m}$. The sea bottom slopes northward and northwestward, for the most part, to the relatively deep water of the Bering Strait. The southeastern part of the Chirikov Basin is a shallow plain at $20-30 \mathrm{~m}$, the northwestern part an area of undulating and hummocky relief, mostly deeper than $30 \mathrm{~m}$. The nearshore zone, locally as much as $10 \mathrm{~km}$ wide and generally shallower than $20 \mathrm{~m}$, is much more complex in relief (Nelson and Hopkins, 1972; Tagg and Greene, 1973).

All of the Chirikov Basin area was exposed above sea level during Pleistocene marine regressions. Thus, the present sea bottom has been affected by subaerial erosional and depositional processes during low-sea-level episodes, by shoreline processes when the strand migrated across the region, and by bottom currents during intervals of flooding. The surface effects of tectonic movements have added to the bathymetric diversity. The configuration of the sea bottom is the summation of processes that have operated throughout the 10-12 m. y. since the continental shelf of Bering Sea was first submerged (Hopkins, 1967). Most of the relief features, however, are products of processes that functioned within the past few tens of thousands of years, during and since the Wisconsinan interval of lowered sea level.

Nearshore areas of exceptionally complex topography, $5-20 \mathrm{~km}$ in width, extend from the strand to depths of $10-30 \mathrm{~m}$ (pl. 1). Small boats are required to complete hydrographic surveys in these hazardous shallow waters, and bottom areas along many segments of the Seward Peninsula and St. Lawrence Island coasts have not yet been charted. Surveys completed, however, show that two quite different types of bottom relief are present beneath the nearshore waters, depending upon whether the bottom is underlain by well-lithified pre-Quaternary rocks or by soft, recently deposited Holocene sediments.

Nearshore hardrock areas generally extend seaward from areas where pre-Quaternary bedrock is exposed at or near the coast. The bottom contours are extremely irregular and complexly indented. Many small, irregular hillocks are scattered among narrow ridges and valleys that extend normal or oblique to the present-day shoreline. Most of the hillocks and ridges probably are formed by outcrops of bedrock on the sea floor. Nearshore hardrock areas are charted on the north coast of St. Lawrence Island between Northeast Cape and Lietnik and on the Seward Peninsula coast between Sledge Island and Cape Rodney and between Lost River and Cape Prince of Wales (pl. 1). An area of irregular bottom topography, which is less than $10 \mathrm{~m}$ deep and extends about $5 \mathrm{~km}$ seaward from the sharp bend in the Point Spencer spit, may also be an area in which well-lithified pre-Quaternary rocks crop out on the sea bottom. Nearshore hardrock areas range in width from as little as $1 \mathrm{~km}$ off Lost River to as much as $12 \mathrm{~km}$ in the Sledge Island area and $18 \mathrm{~km}$ in the Belmezok area.

Nearshore prograded areas extend seaward from barrier bars, spits, and other loci of Holocene shoreline progradation. They are characterized by relatively 
smooth offshore slopes diversified, in places, by relief features that result from active longshore sediment transport. The nearshore prograded areas generally range from $1-4 \mathrm{~km}$ in width. Prograded shorelines are charted off Point Spencer spit and Brevig Lagoon, western Seward Peninsula, and from Cape Prince of Wales northeastward along the north coast of Seward Peninsula (pl. 1).

Microrelief resulting from longshore sediment transport is best displayed in the area north and northeast of Cape Prince of Wales. Ridges about $1 \mathrm{~km}$ long and about $2 \mathrm{~m}$ high, probably sand waves, extend perpendicularly from the shore in a segment of the coast between 5 and $10 \mathrm{~km}$ north of Cape Prince of Wales. To the northeast, the sand waves are replaced by a set of closely spaced submerged ridges that extend en echelon and subparallel to the shore. The longshore ridges are visible on aerial photographs and are shown on unpublished boat sheets; they are typically 1 or 2 $\mathrm{km}$ long, but some can be traced through distances as great as 4 or $5 \mathrm{~km}$. They lie in a belt about a kilometre wide and extend from the strand to a depth of 7 or $8 \mathrm{~m}$. As many as four ridges may be present in any given offshore transect. The crests lie at a depth of $6 \mathrm{~m}$ or less; the intervening swales are 1-3 m deeper.

Many areas of distinctive topography, here called offshore physiographic units, can be distinguished on the sea floor seaward from the nearshore zone (pl. 3) as described below.

The Norton Plain is a monotonously flat, featureless area that extends from near the coast of southcentral Seward Peninsula southwestward to eastern St. Lawrence Island, thence eastward through Norton Sound to the Yukon River delta (pl. 2). Only the western part of the plain, an area of about $11,000 \mathrm{~km}^{2}$, is included in our study area (pl. 3). Some parts of the Norton Plain display less than $2 \mathrm{~m}$ change in depth within distances of $30 \mathrm{~km}$ or more. The central part, which slopes imperceptibly northwestward, grades into the Chirikov Ramp near the 38-m isobath.

The Chirikov Ramp is a broad plain occupying an area of $8,200 \mathrm{~km}^{2}$ that slopes gently northward toward the Bering Strait; it drops from a depth of $38 \mathrm{~m}$ at the boundary with the Norton Plain to a depth of about $50 \mathrm{~m}$ at the junction with the Chukotka Trough. This slope is about double the inclination of the Norton Plain. The surface of this very gentle slope is diversified by roughness of 4 or $5 \mathrm{~m}$ relief that seems to consist of shallow, branching, subparallel swales running straight downslope at intervals of 1 or $2 \mathrm{~km}$ (pls. 1 and 2). The swales appear to terminate at the boundary with the deranged topography of the Chukotka Trough.

The Chirikov Ramp is separated from the Cape Rod- ney Parallel Valley area to the east by the King Island Valley, an almost linear furrow that extends about $70 \mathrm{~km}$ southeastward from King Island at depths of $32-40 \mathrm{~m}$. The King Island Valley is generally 2 or 3 $\mathrm{km}$ wide and lies $5-10 \mathrm{~m}$ below the surrounding sea bottom. On the west, the Chirikov Ramp is bounded by the Kookoolik Valley, a sinuous channel that heads at the northwest corner of the Savoonga Depression about $23 \mathrm{~km}$ northeast of Kookoolik Cape on St. Lawrence Island, and terminates about $65 \mathrm{~km}$ farther north at the juncture of the Chirikov Ramp and the Chukotka Trough. The Kookoolik Valley can be divided into two parts: an upper and a lower course. The upper course is as much as $10 \mathrm{~km}$ wide, and the valley floor stands about $10 \mathrm{~m}$ below areas to the east and west. The lower course is less sharply defined; its floor stands less than $6 \mathrm{~m}$ below the surrounding sea bottom.

The Chukotka Trough is a low-lying area that extends along the U.S.-Russian Convention Line from Anadyr Strait to Bering Strait; it consists of about $10,000 \mathrm{~km}^{2}$ of our study area (pl. 3). It is bordered on the east by Gambell Shoal and the Chirikov Ramp and extends westward, probably to the Siberian coast (pl. 2). The Chukotka Trough lies almost entirely below $-40 \mathrm{~m}$, and depths as great as $60 \mathrm{~m}$ are found in a closed depression a few kilometres south of Bering Strait.

The Chukotka Trough is an area of hillocks, swales, and closed depressions that, in most places, cannot be resolved into a coherent drainage pattern. Although much of the relief appears entirely patternless, an area enclosed by lat $65^{\circ} \mathrm{N}$., long $169^{\circ} 30^{\prime} \mathrm{W}$., and by the International Date Line is interpreted on National Ocean Survey Map $1215 \mathrm{~N}-10$ as containing a set of rectilinear ridges and depressions oriented northeast and northwest. In the area south of lat $64^{\circ} 30^{\prime} \mathrm{N}$., the hillocks, swales, and slopes are strongly oriented $\mathrm{N}$. $45^{\circ} \mathrm{E}$.

Most of the Chukotka Trough displays a local relief of 3-6 m. Three ranges of higher and steeper hills have flat summits at depths of 38 to $40 \mathrm{~m}$ (pl. 1). They represent the eastern terminus of ridges that extend westward toward the Siberian coast (pl. 2). A south-facing scarp, about $10 \mathrm{~m}$ high, crosses the Chukotka Trough at the south entrance to Bering Strait and encloses a large depression that extends some $50 \mathrm{~km}$ southward.

Although most parts of the Chukotka Trough contain no traces of organized drainage, distinct sea valleys are present in Bering and Anadyr Straits. The Bering Strait Valley, at depths of $52-60 \mathrm{~m}$, is about 1 $\mathrm{km}$ wide. It is $6-10 \mathrm{~m}$ deeper than the surrounding sea bottom. The valley extends northward from the southfacing bluff at the south entrance to Bering Strait. The Chaplino Valley is a sinuous, flat-floored sea valley 
1 or $2 \mathrm{~km}$ wide that probably heads near the village of Chaplino on the Siberian coast. It crosses the eastern corner of our study area at $-52-60 \mathrm{~m}$ and appears to have a double channel defined by the $56-\mathrm{m}$ isobath in the area where it turns westward toward the Gulf of Anadyr.

The Cape Rodney Parallel Valley Area, an area of about $4,400 \mathrm{~km}^{2}$ that extends from Sledge Island (west of Nome) past Cape Rodney to the vicinity of King Island, is dominated by broad, low ridges and shallow but sharply defined valleys. Most of the area lies at a depth of $20-38 \mathrm{~m}$. Depths are somewhat greater in the King Island Valley, which forms the southwestern boundary of this physiographic unit. Depths of 38-48 m characterize the part of the Cape Rodney Parallel Valley Area that projects northward between the King Island and Point Spencer Shoal Areas. The parallel valleys are $2-4 \mathrm{~km}$ apart throughout most of this physiographic unit; in the northern projection, they are about $1 \mathrm{~km}$ apart. Most valleys are less than $5 \mathrm{~m}$ below the intervening ridges. The northwestward trend that characterizes the valleys and ridges in the greater part of the area bends in a sweeping curve to a northward trend in the northernmost part. Most of the valleys slope to the northwest, but in the eastern part of the area near Sledge Island, they slope southeast. Several are charted as long, closed depressions, 2 or $3 \mathrm{~m}$ deep.

The Cape Rodney Parallel Valley Area terminates inshore against a more steeply sloping and topographically diversified nearshore area between Sledge Island and Cape Rodney. Northwest of Cape Rodney, the inshore limit of the Cape Rodney Parallel Valley Area cannot be defined because hydrographic surveys terminate from $7-30 \mathrm{~km}$ offshore near the $20-\mathrm{m}$ isobath.

The Point Spencer Shoal Area, about $1,700 \mathrm{~km}^{2}$ between Point Spencer and King Island, is characterized by a series of massive, generally northwesttrending constructional ridges that stand 5-20 m above the intervening lower areas. The ridges are typically 4 or $5 \mathrm{~km}$ wide and are separated by lower ground of approximately equal width. Individual ridges range in length from 15 to $35 \mathrm{~km}$. Most ridges extend, spitlike, from higher ground in the Cape Rodney Parallel Valley Area to the southwest.

Lost River Shoal, the easternmost and shallowest of the shoals, extends about $18 \mathrm{~km}$ northwestward toward Lost River from a convexity in the $10-\mathrm{m}$ isobath that lies about $5 \mathrm{~km}$ off the sharp northward bend in the trend of Point Spencer spit. Detailed inshore surveys indicate that the crest of Lost River Shoal exhibits minor surface roughness and that the crest lies at depths of 8-12 $\mathrm{m}$. The shoal stands only 4 or $5 \mathrm{~m}$ above low ground to the east and west.
The base of York Shoal lies at the 20-m isobath, about $25 \mathrm{~km}$ southwest of the bend in Point Spencer spit, and extends northward in a sweeping inflected curve some $22 \mathrm{~km}$ toward Cape York. The crest lies at $15-20 \mathrm{~m}$ and is diversified by a set of spectacular sand waves (Grim and McManus, 1970). The area between York Shoal and Lost River Shoal is characterized by rather irregular topography at $-14-20 \mathrm{~m}$. Closed depressions are present in the low ground, and there is a low ridge about $6 \mathrm{~km}$ long with crestal depths of $-12-16 \mathrm{~m}$ that may be another constructional feature.

Tin City Shoal begins at a projection in the $20-\mathrm{m}$ isobath about $30 \mathrm{~km}$ southwest of the bend in Point Spencer and extends about $25 \mathrm{~km}$ northwestward toward Tin City. The crest of the shoal lies at a depth of 20-22 m. Detailed inshore surveys terminate at York Shoal; the relatively smooth contours of Tin City Shoal and other shoals farther west in part reflect the lack of detailed hydrographic data. However, inspection of our high-resolution seismic records indicates that the sand waves that complicate the crestal topography of York Shoal are absent on the deeper shoals. The southeastern third of the Tin City Shoal exhibits considerable microrelief; the northwestern part appears to slope gently and smoothly northwestward. The area between Tin City and York Shoals is occupied by a broad valley that slopes northward toward the Port Clarence Valley.

Ukivok Shoal, named after Ukivok village on King Island, has its base at a projection in the $32-\mathrm{m}$ isobath about $35 \mathrm{~km}$ southwest of Point Spencer spit and extends from there about $35 \mathrm{~km}$ northwestward. Like Tin City Shoal, Ukivok Shoal seems to be relatively smooth. Depths at the crest range from 30 to $32 \mathrm{~m}$. The area between Ukivok and Tin City Shoals is a broad swale containing several large closed depressions at a depth of about $36 \mathrm{~m}$.

Another set of ridges radiate from King Island in an area of about $160 \mathrm{~km}^{2}$. The dominant submerged feature is King Island Shoal, a constructional ridge about $4 \mathrm{~km}$ wide and $12 \mathrm{~km}$ long that slopes gently northwestward from the island. Near the island, the crest of King Island Shoal is at a depth of $26 \mathrm{~m}$, about 18 or $20 \mathrm{~m}$ higher than the surrounding sea bottom. Lower and more lobate ridges radiate eastward and southward from King Island. On the west side of King Island, there is a west-trending closed depression with a maximum depth exceeding $50 \mathrm{~m}$, at least $6 \mathrm{~m}$ deeper than the surrounding sea bottom.

The Wales Hills represent a northern and more hilly continuation of the northern projection of the Cape Rodney Parallel Valley Area. The hills, which extend northward about $37 \mathrm{~km}$ and occupy an area of about $300 \mathrm{~km}^{2}$, form a belt of complex relief about $5 \mathrm{~km}$ 
wide at the eastern margin of the Chukotka Trough. Individual hills are $2-4 \mathrm{~km}$ long, $1-2 \mathrm{~km}$ wide, and stand 8-10 $\mathrm{m}$ above the intervening rather flat areas. The hill summits are mostly at depths of $44-48 \mathrm{~m}$. The boundary with the Cape Rodney Parallel Valley Area consists of a gradual transition from parallel northoriented depressions to parallel north-oriented ovate hills. Farther north, the hills are equidimensional; still farther north, they are ovate with axes oriented east-west.

The Port Clarence Valley is a nearly straight trench that extends from Port Clarence $50 \mathrm{~km}$ westward along the coast of western Seward Peninsula to the Wales Hills; this unit forms the northern boundary of the Point Spencer Shoal Area. The valley is asymmetrical: the north wall is an abrupt slope, locally a scarp as much as $12 \mathrm{~m}$ high; the south wall is a gentler slope leading down from sea bottom areas that stand $2-10 \mathrm{~m}$ higher than the valley axis. The valley bottom is $4-5 \mathrm{~km}$ wide and slopes westward to a large closed depression, about $4 \mathrm{~m}$ deep (bottoming below $-54 \mathrm{~m}$ ) and $12 \mathrm{~km}$ long; the valley is confined by the higher ground of the Wales Hills.

The Belmezok Area is a triangular region of rugged and diversified topography that occupies about 1,000 $\mathrm{km}^{2}$ south and southeastward from the abandoned village of Belmezok, near Wales on the eastern shore of Bering Strait. Depth ranges from $20 \mathrm{~m}$ at the inshore margin of the Belmezok area to about $50 \mathrm{~m}$ at the boundary with the Wales Hills to the southeast and the Port Clarence Valley to the south. The topography of the Belmezok area is similar to, but deeper than, that of the nearshore hard-rock areas; it consists of numerous diversely oriented ridges, valleys, scarps, and undulating, terracelike flats, probably formed mainly by subaerial and shoreline processes acting upon hard, crystalline rocks. Local relief on some of the scarps and ridges is as great as $10 \mathrm{~m}$.

Prince of Wales Shoal is a large constructional ridge extending northward some $130 \mathrm{~km}$ from Cape Prince of Wales (McManus and Creager, 1963). Almost entirely in the Chukchi Sea, it occupies a total area of about $5,000 \mathrm{~km}^{2}$, of which only about $400 \mathrm{~km}^{2}$ lies within the area of the northern Bering Sea as mapped on plate 1 . The summit of the shoal within our area lies at depths of 8-10 m. The west slope is a steep $30-\mathrm{m}$ face descending to the Chukotka Trough; the east side slopes gently to the flat floor of Kotzebue Sound, which here lies at a depth of only $16-18 \mathrm{~m}$.

The south entrance to Anadyr Strait is partly obstructed by a nested pair of broadly curving ridges, convex toward the south, that extend westward from the west coast of St. Lawrence Island at the south end of the Chukotka Trough (pl. 1). Booshu Spur, the more southern ridge, has its base at the $40-\mathrm{m}$ isobath off Booshu Camp and slopes about $50 \mathrm{~km}$ westward, terminating at a depth of $62 \mathrm{~m}$. Booshu Spur has an average width of about $25 \mathrm{~km}$ and an area of about $1,400 \mathrm{~km}^{2}$. As contoured on NOS Chart $1814 \mathrm{~N}-10$, the summit of the spur appears to be a smoothly convex surface with little microrelief. Sevuokuk Spur, lying immediately to the north, is higher, sharper, and narrower. The base of the spur lies somewhere inshore from the 36-m isobath off Mount Sevuokuk; it slopes about $40 \mathrm{~km}$ westward to a depth of $58 \mathrm{~m}$. Sevuokuk Spur is $10-15 \mathrm{~km}$ wide and encompasses an area of about $500 \mathrm{~km}^{2}$. Microrelief on the ridge crest appears to be considerably more complex than the microrelief on Booshu Spur, but this may be a cartographic artifact reflecting more closely spaced hydrographic survey lines in the area of the Sevuokuk Spur.

Gambell Shoal is a broad, bathymetrically high area of about $5,700 \mathrm{~km}^{2}$ that extends nearly $100 \mathrm{~km}$ northeastward from western St. Lawrence Island. The larger part of the ridge lies at depths of $20-30 \mathrm{~m}$, but the northeastern third slopes gently down to a depth of about $40 \mathrm{~m}$. The northwest flank of the ridge is a smooth, gentle slope that descends about $10 \mathrm{~m}$ in 8 or 9 $\mathrm{km}$ to the floor or the Chukotka Trough. The east flank is a strongly dissected slope that descends to the Savoonga Depression and the Kookoolik Valley.

The summit area of Gambell Shoal has a diversified topography rather similar to the topography that characterizes much of the Chukotka Trough. Hillocks and swales of diverse orientation and a local relief of 2-4 m occur throughout most of the ridge (pl. 1). In the southernmost part, near St. Lawrence Island, the relief is higher and more organized, consisting of northeasttrending ridges and hillocks $3-4 \mathrm{~km}$ long and 6-8 km high.

Several northwest-trending, valleylike topographic lineaments cross the Gambell Shoal. The most conspicuous is a shallow trench that extends about $45 \mathrm{~km}$ in a N. $45^{\circ} \mathrm{W}$. orientation from the Savoonga Depression; the trench nearly bisects Gambell Shoal (pl. 1). The topographic lineament continues southeastward from the east side of the Savoonga Depression as a long, shallow sea valley, $50 \mathrm{~km}$ long, incised into the southwest corner of the Norton Plain.

The Savoonga Depression is a closed basin that occupies about $660 \mathrm{~km}^{2}$ north and northeast of Savoonga village on the north coast of St. Lawrence Island. The basin is enclosed by the higher ground of Gambell Shoal to the west, the Norton Plain to the east, and St. Lawrence Island to the south. The head of Kookoolik Valley forms a gap or saddle in the north wall at a depth of $38 \mathrm{~m}$. The most conspicuous features of the basin floor are two arcuate ridges with steep 
sides and nearly flat tops that extend northeastward from the steep offshore slope of central St. Lawrence Island. The more eastern ridge is at least $5 \mathrm{~km}$ long and $10-20 \mathrm{~m}$ high; the other, at least $16 \mathrm{~km}$ long, consists of three segments separated from one another by deep notches or saddles. Between the ridges, the floor of the Savoonga Depression is an undulating surface containing several flat-floored depressions at depths of $42-52 \mathrm{~m}$.

Northeast Cape Shoal is a smooth, subtle constructional ridge of broadly arcuate outline that occupies an area of about $1,000 \mathrm{~km}^{2}$ off Northeast Cape, St. Lawrence Island. The shoal extends southeastward into Sphanberg Strait. As the summit of the shoal lies at -25 or $26 \mathrm{~m}$, the crest stands only $5-10 \mathrm{~m}$ above the Norton Plain to the north. The concave southern side of Northeast Cape Shoal encloses a set of convergent south- and east-trending sea valleys that merge at a depth of about $46 \mathrm{~m}$ near the southeastern boundary of the area of plate 3 to form the head of the St. Lawrence Trough, an elongate bathymetric depression locally as deep as $50 \mathrm{~m}$, which extends about $100 \mathrm{~km}$ southward from the east end of St. Lawrence Island (Knebel and others, 1974).

\section{DISCUSSION}

A systematic bathymetric survey has shown that the morphology of the floor of the northern Bering Sea is more complex than had been expected. The region is tectonically active; some of the topographic features are fault scarps (Grim and McManus, 1970) and others may be the surface expression of growing folds. The northern Bering Sea is shallow enough to have been emergent as a part of the Bering Land Bridge during the last glaciation. Glacial and fluvial processes have left their mark upon the sea floor (Hopkins, 1972), and traces of ancient shorelines, formed during pauses in the last rise in sea level, can be recognized (Hopkins, 1973). The Norton Plain represents the depositional surface of sediment recently introduced by the Yukon River (McManus and others, 1974). Other constructional and streamlined features can be identified as formed or modified by bottom currents during the several millenia since sea level reached its present-day position.

\section{REFERENCES CITED}

Bezrukov, P. L., ed., 1959, Geographical description of the Bering Sea: Bottom relief and sediments: Akad. Nauk SSSR, Inst. Okeanologii, Trudy, v. 29 (Translation pub. by Israel Program for Sci. Translations, Jerusalem, 1964, 188 p.).

Creager, J. S., and McManus, D. A., 1967, Geology of the floor of Bering and Chukchi Seas-American studies, in Hopkins, D. M., ed., The Bering Land Bridge: Stanford, Calif., Stanford Univ. Press, p. 7-31.
Dietz, R. S., Carsola, A. J., Buffington, E. C., and Shipek, C. J., 1964, Sediments and topography of the Alaskan shelves, in Miller, R. L., ed., Papers in marine geology_Shepard Commemorative Volume: New York, MacMillan Co., p. 241-256.

Gershanovich, D. E., 1967, Late Quaternary sediments of Bering Sea and the Gulf of Alaska, in Hopkins, D. M., ed., The Bering Land Bridge: Stanford, Calif., Stanford Univ. Press, p. 32-46.

Grim, M. S., and McManus, D. A., 1970, A shallow seismic-profiling survey of the northern Bering Sea: Marine Geology, v. 8, p. 293-320.

Hood, D. W., and Kelley, E. J., 1974, Oceanography of the Bering Sea: Alaska Univ. Inst. Marine Sci., Oceanog. Pub. 2, 623 p.

Hopkins, D. M., ed., 1967, The Bering Land Bridge: Stanford, Calif., Stanford Univ. Press, $495 \mathrm{p}$.

1972, The paleogeography and climatic history of Beringia during Late Cenozoic time: Internord, no. 12, p. 121-150.

1973, Sea level history in Beringia during the past 250,000 years: Quaternary Research, v. 3, p. 520-540.

Hopkins, D. M., Rowland, R. W., and Patton, W. W., 1973, Middle Pleistocene mollusks from St. Lawrence Island and their significance for the paleo-oceanography of the Bering Sea: Quaternary Research, v. 2, p. 119-134.

Knebel, H. J., Creager, J. S., and Echols, R. J., 1974, Holocene sedimentary framework, east-central Bering Sea continental shelf, in Herman, Y., ed., Marine geology and oceanography of the Arctic seas: New York-Heidelberg-Berlin, Springer Verlag, p. 157-172.

Lisitsyn, A. P., 1966, Recent sedimentation in the Bering Sea: Acad. Sci. USSR, Dept. Earth Sci., Comm. Sed. Rocks, Inst. Oceanology Moscow (Translation pub. by Israel Program for Sci. Translations, Jerusalem, 1969, 614 p.).

McManus, D. A., and Creager, J. S., 1963, Physical and sedimentary environments on a large spit-like shoal: Jour. Geology, v. 71, p. 498-512.

McManus, D. A., and Smyth, C. S., 1970, Distribution and transport of suspended material through the straits of northern Bering Sea: Jour. Sed. Petrology, v. 40, p. 869-873.

McManus, D. A., Kelly, J. C., and Creager, J. S., 1969, Continental shelf sedimentation in an arctic environment: Geol. Soc. America Bull., v. 80, p. 1961-1984.

McManus, D. A., Venkatarathnam, K., Nelson, C. H., and Hopkins, D. M., 1974, Yukon sediment on the northernmost Bering Sea shelf: Jour. Sed. Petrology, v. 44, p. 1052-1060.

McManus, D. A., Kolla, V., Hopkins, D. M., and Nelson, C. H., 1977, Distribution of bottom sediments on the continental shelf, northern Bering Sea: U.S. Geol. Survey Prof. Paper 759-C (in press).

Moll, R. F., 1970, Clay mineralogy of the north Bering Sea shallows: Univ. Southern Calif., Geol. Dept., M.S. thesis, 101 p.

Moore, D. G., 1964, Acoustic-reflection reconnaissance of continental shelves-eastern Bering and Chukchi Seas, in Miller, R. L., ed., Papers in marine geology-Shepard Commemorative Volume: New York, MacMillan Co., p. 319-362.

Nelson, C. H., 1971, Northern Bering Sea, a model for depositional history of Arctic shelf placers-ecological impact of placer development; Internat. Conf. Port and Ocean Engineèring under Arctic Conditions, 1st, Proc., v. 1, p. 246-254.

Nelson, C. H., and Hopkins, D. M., 1972, Sedimentary processes and distribution of gold in northern Bering Sea: U.S. Geol. Survey Prof. Paper 689, 27 p.

Nelson, C. H., Hopkins, D. M., and Scholl, D. W., 1974, Tectonic setting and Cenozoic sedimentary history of the Bering Sea, in Herman, Y., ed., Marine geology and oceanography of the Arctic seas: New York-Heidelberg-Berlin, Springer Verlag, p. 119 140 . 
Nelson, C. H., Pierce, D. E., Leong, K. W., and Wang, F. H., 1975, Mercury distribution in ancient and modern sediment of northeastern Bering Sea: Marine Geology, v. 18, p. 91-104.

Scholl, D. W., and Hopkins, D. M., 1969, Newly discovered Cenozoic basins, Bering shelf, Alaska: Am. Assoc. Petroleum Geologists Bull., v. 53, p. 2067-2078.

Sheth, Madhusudan, 1971, A heavy mineral study of Pleistocene and Holocene sediments near Nome, Alaska: San Jose State College, San Jose, Calif., Dept. Geol., M.S. thesis, 83 p.

Silberman, M. L., 1969, Preliminary report on electron microscopic examination of surface texture of quartz sand grains from the Bering shelf: U.S. Geol. Survey Prof. Paper 650-C, p. C33-C37.

Tagg, A. R., and Greene, H. G., 1973, High-resolution seismic survey of a nearshore area, Nome, Alaska: U.S. Geol. Survey Prof. Paper 759-A, p. A1-A23.

Udintsev, G. B., Boichenko, I. G., and Kanaev, V. F., 1959, Bottom relief of the Bering Sea, p. 14-64, in Bezrukov, P. L., ed., Geographical description of the Bering Sea: Acad. Nauk SSSR, Inst. Okeanologii, Trudy, v. 29 (English translation by Israel Program for Sci. Translations, 1964).

Venkatarathnam, K., 1971, Heavy minerals on the continental shelf of the northern Bering Sea, in Bottom samples and seismic profiles of the northern Bering Sea, and associated studies: U.S. Geol. Survey open-file rept., p. 2-93.

Walton, F. W., Perry, R. B., and Greene, H. G., 1969, Seismic reflection profiles, northern Bering Sea: U.S. Dept. Commerce ESSA, Operational Data Rept. C\&GS DR 8, 17 p. 
